\title{
Metode Sayyid Quthb dalam menafsirkan ayat-ayat mengenai kepemilikan dan harta (pembacaan terhadap Tafsir Fî Zhilâl al- Qur'ân)
}

\author{
Mujiatun Ridawati1, Muhamad Johari2,* \\ Institut Agama Islam Qamarul Huda, Indonesia ${ }^{1}$ \\ Universitas Islam Negeri Mataram, Indonesia ${ }^{2}$ \\ Corresponding e-mail: muhamad.johari@uinmataram.ac.id*
}

\begin{abstract}
submitted: Revelation in the form of a holy book (al-Qur'an) is often addressed to all Sep-17, 2019 humans, regardless of their circumstances or mindsets. Thus, it is entirely conceivable and even necessary for the creation of numerous distinct accepted: interpretations. One straightforward and obvious conclusion from these varied Oct-03, 2019 readings is that humans have an unequal capacity to comprehend the essence of revelation. It can be argued that Sayyid Quthb's thoughts are difficult to published: comprehend unless one is willing to read them thoroughly and possesses Dec-02, 2019 adequate language skills. Sayyid Quthb employs the tafsr bi ar-ra'yi method, in which he defines property as "everything that can be utilised by humans in carrying out their duties as creatures of Allah." According to Sayyid Quthb, property belongs to Allah swt. entirely, regardless of its form. According to Sayyid Quthb, jihad is an aggressive war waged against Islam's physical adversary through a complete separation of Muslim and non-Muslim ties. According to the preceding definition of jihad, Sayyid Quthb assumes that wealth is merely a tool to be employed in the service of Allah during jihad.
\end{abstract}

Keywords: kepemilikan, sayyid quthb, tafsir

Journal of Enterprise and Development (JED) is licensed under a Creative Commons AttributionShareAlike 4.0 International License. 


\section{PENDAHULUAN}

Salah satu pokok ajaran Islam adalah beriman kepada kitab suci. Iman dalam hal ini berlaku atas semua kitab suci yang telah diturunkan oleh sang pencipta, Allah swt., kepada para utusan-Nya. Namun demikian, di antara beberapa kitab suci yang harus dipercayai akan keberadaan dan kebenarannya, Allah swt. menegaskan bahwa al-Qur'an satu-satunya kitab suci yang harus dipelajari, dipahami, dan diamalkan ajarannya oleh umat Islam.

Adanya perintah tersebut didasarkan pada kenyataan bahwa al-Qur'an merupakan penyempurna ajaran yang tercakup dalam kitab suci lainnya. Selain itu, al-Qur'an juga mencakup segala pokok ajaran keagamaan dalam hal ibadah maupun mu'amalah yang dapat menjadi tolak ukur dan panutan bagi umat manusia.

Allah swt. berfirman mengenai fungsi al-Qur'an,

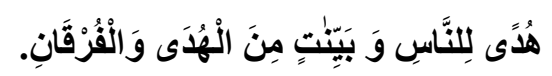

"...sebagai petunjuk bagi manusia dan penjelasan-penjelasan mengenai petunjuk itu dan pembeda (antara yang benar dan yang batil)...." (al-Baqarah [2]: 185)

Menurut pengertian ayat di atas dapat dipahami bahwa al-Qur'an merupakan wahyu Allah swt. yang diturunkan kepada umat-Nya melalui Rasulullah saw. sebagai petunjuk tertulis yang menjelaskan aturan-aturan yang seharusnya serlaku dan diterapkan dalam kehidupan umat manusia. Wahyu yang berupa kitab (al-Qur'an) ini pada umumnya ditujukan kepada manusia secara umum dengan berbagai kondisi dan pola pikir yang berbeda. Sehingga sangat mungkin bahkan menjadi sebuah keharusan akan munculnya berbagai macam penafsiran yang beragam. Satu jawaban singkat dan logis dari penafsiran yang beragam ini adalah ketidaksamaan kemampuan manusia dalam memahami substansi wahyu. Dalam hadist disebutkan bahwa, "Kami para nabi diperintah untuk berkata kepada manusia (menyebarkan ajaran-Nya) sesuai dengan tingkatan kemampuan berpikirnya". ${ }^{1}$ Adalah Sayyid Quthb, seorang ilmuwan, sastrawan sekaligus pemikir dari Mesir yang turut memberikan kontribusi keilmuannya dalam bidang tafsir al-Qur'an, hal ini dapat kita temukan dalam salah satu karyanya di bidang tafsir yang bertajuk "Fî Zhilâl al-Qur'ân" (Di Bawah Naungan Al-Qur'an). Untuk lebih memudahkan pembahasan, tentunya diperlukan rumusan berikut batasan masalah di mana pokok bahasan lainnya hanyalah sebagai pelengkap saja.

\footnotetext{
${ }^{1}$ Muhlis Yusuf Arbi', "Metodologi Penafsiran Al-Qur'an", dipublikasikan melalui http://akangjabrik.wordpress.com/2007/12/14/metodologi-penafsiran-alqur\%E2\%80\%99an/, diakses pada tanggal 04 Januari 2008.
} 


\section{PEMBAHASAN}

\section{Harta dan kepemilikan}

Al-Mâl dalam bahasa Arab berasal dari kata kerja "mâla" yang berarti condong atau berpaling dari tengah ke salah satu sisi. sedangkan arti kata "al-mâl" itu sendiri adalah harta, yaitu segala sesuatu yang menyenangkan manusia dan mereka pelihara, baik dalam bentuk materi maupun dalam bentuk manfaat.

\section{Ulama fikih membagi harta menjadi beberapa macam.}

a. Berdasarkan kebolehan pemanfaatannya menurut syara', harta dibagai menjadi harta mutaqawwim (halal untuk dimanfaatkan) dan harta ghair mutaqawwim (tidak halal untuk dimanfaatkan).

b. Berdasarkan jenisnya,harta terbagi atas harta tidak bergerak (contoh: rumah dan tanah) dan harta bergerak (contoh: pena, buku, dan baju).

c. Berdasarkan segi pemanfaatannya, harta terbagi atas harta isti'mâlî (pemanfaatannya tidak menghabiskan benda seperti lahan pertanian, rumah, dan buku) dan harta istihlâkî (pemanfaatannya menghabiskan benda seperti sabun, pakaian, dan makanan).

d. Berdasarkan ada atau tidaknya harta sejenis di pasaran, terbagi atas harta yang bersifat al-mitslî (harta yang ada jenisnya di pasaran, yaitu harta yang ditimbang atau ditakar seperti gandum, beras, dan besi) dan harta yang bersifat al-qimmî (harta yang tidak ada jenisnya di pasaran atau ada jenisnya tetapi pada setiap satuannya berbeda secara kualitas seperti pepohonan, logam mulia, dan alat-alat rumah tangga).

e. Berdasarkan statusnya, harta terbagi atas tiga jenis, yaitu: Al-mâl al-mamlûk (harta yang telah dimiliki, baik secara pribadi maupun badan hukum seperti Negara dan organisasi kemasyarakatan); Al-mâl al-mubâh (harta yang tidak dimiliki seseorang seperti air di sumbernya, hewan buruan, kayu di hutan belantara yang belum dijamah atau dimiliki orang, dan ikan di lautan lepas); dan Al-mâl al-mahjûr (harta yang dilarang syara' untuk dimiliki baik karena harta tersebut dijadikan harta wakap maupun diperuntukkan bagi kepentingan umum. Harta seperti ini tidak boleh dimanfaatkan untuk kepentingan pribadi tertentu).

f. Berdasarkan segi bisa dibagi atau tidaknya harta, ulama fikih membedakannya menjadi harta yang bisa dibagi dan harta yang tidak bisa dibagi.

g. Berdasarkan segi berkembang atau tidaknya, baik melalui upaya manusia maupun dengan sendirinya berdasarkan ciptaan Allah swt., ulama fikih membaginya menjadi Al-ashl (harta yang menghasilkan seperti rumah, tanah, pepohonan, dan hewan) dan Ats-tsamr (buah yang dihasilkan dari suatu harta seperti sewa rumah, buah-buahan dari pepohonan, dan susu kambing/ sapi). 
h. Berdasarkan pemiliknya, harta dibagi atas harta milik pribadi dan harta milik masyarakat umum ${ }^{2}$

Sedangkan milik dalam bahasa Arab adalah al-Milk yang berarti penguasaan terhadap sesuatu (harta).

Milik dapat dipahami sebagai hubungan seseorang dengan suatu harta yang diakui oleh syara', yang menjadikannya mempunyai kekuasaan khusus terhadap harta tersebut sehingga ia dapat melakukan tindakan hukum terhadap harta tersebut, kecuali ada halangan syara'.

Menurut ulama fikih, ada empat cara pemilikan harta yang disyariatkan Islam, yaitu.

a. I $\underline{h}$ âz al-Mubâhâat, yaitu melalui penguasaan terhadap harta yang belum dimiliki seseorang atau badan hukum lainnya (dalam Islam lebih dikenal dengan harta mubah).

b. Melalui suatu akad/ transaksi yang dilakukannya dengan orang atau suatu badan hukum seperti jual beli, hibah, dan wakaf.

c. Melalui khalâfiyah (penggantian); baik penggantian dari seseorang kepada orang lain (waris), maupun penggantian sesuatu dari suatu benda yang biasa disebut tadmîn atau ta'wîdh (ganti rugi).

d. Melalui tawallud min mamlûk, yaitu hasil/ buah dari harta yang telah dimiliki seseorang; baik hasil itu datang secara alami maupun memalui suatu usaha pemiliknya.

Dari segi tabiat/ sifatnya, kepemilikan terbagi menjadi dua bentuk, yaitu.

a. Milik sempurna (al-Milk at-Tâm), yaitu apabila materi dan manfaat harta itu dimiliki sepenuhnya oleh seseorang sehinga seluruh hak yang terkait dengan harta itu berada di bawah penguasaannya.

b. Milik tak sempurna (al-Milk an-Nâqish), yaitu apabila seseorang hanya menguasai materi harta itu tetapi manfaatnya dikuasai orang lain. Dapat terjadi melalui lima cara, yaitu I'ârah (pinjam meminjam), ijârah (sewa menyewa), wakaf, wasiat, dan ibâhah (penyerahan manfaat milik seseorang kepada orang lain).

Sedangkan dari segi obyek, kepemilikan terbagi menajdi tiga bentuk, yaitu.

a. Milk an-'Ain, yaitu kepemilikan berupa benda; baik benda tetap maupun bergerak.

b. Milk al-Manfa'ah, yaitu kepemilikan terhadap manfaat suatu benda.

c. milk ad-Dain, yaitu kepemilikan terhadap hutang yang ada pada orang lain. ${ }^{3}$

${ }^{2}$ Ensiklopedi Hukum Islam, Abdul Aziz Dahlan ed., cet.1 (Jakarta: Ikhtiar Van Hoeve, 1996)

Pengertian Harta.

${ }^{3}$ Ibid. Pengertian Milik 
Journal of Enterprise and Development (JED), Vol. 1, No. 2, December 2019

Demikianlah pengertian harta dan kepemilikan dari segi bahasa berikut pendapat para ulama berkaitan dengan pembagiannya.

\section{Metodologi dalam penafsiran al-Qur'an}

Ilmu tafsir merupakan ilmu yang paling mulia dan paling tinggi kedudukannya, karena pembahasannya berkaitan dengan Kalamullah yang merupakan petunjuk dan pembeda dari yang haq dan bathil. Ilmu tafsir telah dikenal sejak zaman Rasulullah dan berkembang hingga di zaman modern sekarang ini.

Dilihat dari metode penafsiran dan coraknya, tafsir digolongkan menjadi dua, yaitu tafsir bi al-ma'tsur (riwayah) dan tafsir bi ar-ra'yi (Diroyah).

Metode penafsiran tafsir bi al-ma'tsur terfokus pada Shahih al-Manqûl (riwayat yang shahih) dengan menggunakan penafsiran al-Qur'an dengan al-Qur'an, penafsiran al-Qur'an dengan sunnah, penafsiran al-Qur'an dengan perkataan para sahabat dan penafsiran al-Qur'an dengan perkataan para tabi'in, yang mana sangat teliti dalam menafsirkan ayat sesuai dengan riwayat yang ada.

Penafsiran seperti inilah yang sangat ideal yang patut dikembangkan. Beberapa contoh kitab tafsir yang menggunakan metode ini adalah : Tafsir at-Tobary, Tafsir Ibnu Katsir, Tafsir al-Baghawy, dan Tafsir Imam as-Suyuthy.

Adapun metode penafsiran tafsir bi ar-ra'yi dibagi menjadi dua, yaitu Ar-ra'yu alMahmûdah dan Ar-ra'yu al-Madzmûmah.

Metode Ar-ra'yu al-Mahmûdah menafsirkan Al-Qur'an menggunakan akal yang diperbolehkan dengan beberapa syarat yaitu:

1. Ijtihad yang dilakukan tidak keluar dari nilai-nilai al-Qur'an dan as-Sunnah.

2. Tidak berseberangan penafsirannya dengan penafsiran bi alma'tsur. Seorang mufassir harus menguasai ilmu-ilmu yang berkaitan dengan tafsir beserta perangkat-perangkatnya.

Beberapa contoh kitab tafsir yang menggunakan metode ini antara lain: Tafsir al-Qurthuby, Tafsir al-Jalalain, dan Tafsir al-Baidhawy.

Sedangkan metode Ar-ra'yu al-Madzmûmah melakukan penafsiran dengan akal yang dilarang karena bertumpu pada penafsiran makna dengan pemahamannya sendiri. Dan istinbâth (pegambilan hukum) hanya menggunakan akal/ logika semata yang tidak sesuai dengan nilai-nilali syariat Islam. Kebanyakan metode ini digunakan oleh para ahli bid'ah yang sengaja menafsirkan ayat al-Qur'an sesuai dengan keyakinannya untuk mengajak orang lain mengikuti langkahnya. Juga banyak dilakukan oleh ahli tafsir periode sekarang ini. ${ }^{4}$

\footnotetext{
${ }^{4}$ Abu Salma, "Sejarah Tafsir dan Perkembangannya", dipublikasikan melalui http://www.geocities.com/abu amman/Tafsir.htm/accesse, diakses pada tanggal 04 Januari 20018.
} 


\section{Biografi keilmuan Sayyid Quthb ${ }^{5}$}

Adalah Asy-Syahid Sayyid Quthb, dilahirkan pada tahun 1906 di kampung Musyah, kota Asyut, Mesir.

Musyah merupakan sebuah desa dengan tradisi agama yang kental. Ia juga dibesarkan di dalam sebuah keluarga yang menitikberatkan ajaran Islam dan mencintai al-Qur'an. Dengan tradisi dan keluarga yang seperti itu, maka tak heran jika Quthb kecil menjadi seorang anak yang pandai dalam ilmu agama. bahkan, saat usianya masih belia, ia telah bergelar hafizh, yaitu sebelum berumur sepuluh tahun.

Menyadari bakat dan kepandaian menyerap ilmu yang besar pada diri anaknya, orang tuanya memindahkan keluarganya ke Helwan, daerah pinggiran Kairo.

Kesempatan yang diperolehnya untuk lebih berkembang di luar kota asal tak disia-siakan oleh Quthb. Semangat dan kemampuan belajar yang tinggi ia tunjukkan pada kedua orang tuanya. Sebagai buktinya, ia memperoleh kesempatan masuk Tajhijiyah Dârul 'Ulûm. Tahun 1929, ia kuliah di Dârul 'Ulûm (nama lama Universitas Kairo, sebuah universitas yang terkemuka dalam bidang pengkajian ilmu Islam dan bahasa Arab, juga tempat al-Imam Hasan Al-Banna belajar sebelumnya). Ia memperoleh gelar sarjana muda pendidikan pada tahun 1933.

Ayahnya dipanggil ke hadirat Yang Maha Kuasa ketika ia sedang kuliah. Tak lama kemudian (1941), ibunya pun menyusul kepergian suaminya. Wafatnya dua orang yang dicintainya itu membuatnya merasa sangat kesepian. Tetapi di sisi lain, keadaan ini justru memberikan pengaruh positif dalam karya tulis dan pikirannya.

Sejak dari lulus kuliah hingga tahun 1951, kehidupannya tampak biasa-biasa saja, sedangkan karya tulisnya menampakkan nilai sastra yang begitu tinggi dan bersih, tidak bergelimang dalam kebejatan moral seperti kebanyakan sastrawan pada masa itu. Pada akhirnya, tulisan-tulisannya lebih condong kepada Islam.

Pada tahun yang sama, sewaktu bekerja sebagai pengawas sekolah di departemen pendidikan, ia mendapat tugas belajar ke Amerika Serikat untuk memperdalam pengetahuannya di bidang pendidikan selama dua tahun. Ia membagi waktu studinya antara Wilson's Teacher's College di Washington, Greeley College di Colorado, dan Stanford niversity di California. Ia juga banyak mengunjungi banyak kota besar di Amerika Serikat serta berkunjung ke Inggris, Swiss, dan Italia.

Tidak seperti rekan-rekan seperjalanannya, keberangkatannya ke Amerika itu ternyata memberikan saham yang besar pada dirinya dalam menumbuhkan kesadaran dan semangat Islami yang sebenarnya. Terutama setelah ia melihat bangsa Amerika berpesta pora atas meninggalnya al-Imam Hasan al-Banna pada awal tahun 1949.

${ }^{5}$ Sayyid Quthb, Fî Zhilâl al-Qur'an, terjemah oleh As'ad Yasin, Abdul Aziz Salim Basyarahil, Muchotob Hamzah, Gema insani Press, cet III april 2006, hal. 386-387. 
Hasil studi dan pengalamannya selama di AS itu meluaskan wawasan pemikirannya mengenai problem-problem sosial kemasyarakatan yang ditimbulkan oleh paham materialisme yang gersang akan paham ketuhanan. Ketika kembali ke Mesir, ia semakin yakin bahwa Islamlah yang sanggup menyelamatkan manusia dari paham materialisme sehingga terlepas dari cengkeraman materi yang tak pernah terpuaskan.

Sayyid Quthb kemudian bergabung gerakan Islam Ikhwanul Muslimin dan menjadi salah seorang tokohnya yang berpengaruh, di samping Hasan al-Hudaibi dan Abdul Qadir Audah.

Sewaktu larangan terhadap IM dicabut pada tahun 1951, ia terpilih sebagai anggota panitia pelaksana dan memimpin bagian da'wah. Selama tahun 1953, ia menghadiri konferensi di Suriah dan Yordania, dan sering memberikan ceramah tentang pentingnya akhlak sebagai prasyarat kebangkitan umat.

Juli 1954, ia menjadi pimpinan redaksi harian IM. Akan tetapi, baru dua bulan usianya, harian itu ditutup atas perintah Presiden Mesir Kolonel Gamal Abdul Nasr karena mengecam perjanjian Mesir-Inggris 7 juli 1954.

Sekitar mei 1955, Sayyid Quthb temasuk salah seorang pemimpin IM yang ditahan setelah organisasi itu dilarang oleh Presiden Nas dengan tuduhan berkomplot untuk menjatuhkan pemerintahan.

Pada 13 juli 1955, Pengadilan Rakyat menjatuhkan hukuman lima belas tahun kerja berat. Ia ditahan di beberapa penjara di Mesir hingga pertengahan tahun 1964. ia dibebaskan pada tahun itu atas permintaan presiden Irak Abdussalam Arif yang melaksanakan kunjungan muhibah ke Mesir.

Baru setahun ia menikmati kebebasan, ia kembali ditangkap bersama tiga orang saudaranya: Muhammad Quthb, Hamidah, dan Aminah. Juga ikut ditahan sekitar 20.000 orang lainnya, 700 diantaranya wanita.

Pada hari senin, 13 jumadil awal 1386 atau 29 Agustus 1966, ia dan dua orang temannya (Abdul Fattâh Ismail dan Muhammad Yusuf Hawwasy) menyambut panggilan Rabbnya dan syahid di tali tiang gantungan.

Meski berbagai kalangan dari dunia internasional telah mengecam Mesir atas hukuman tersebut, Mesir tetap saja bersikukuh seperti batu. Sebelum menghadapi ekskusinya dengan gagah berani, Sayyid Quthb sempat menuliskan corat-coret sederhana, tentang pertanyaan dan pembelaannya. Kini corat-coret itu telah menjadi buku berjudul, "Mengapa Saya Dihukum Mati?"

Sebuah pertanyaan yang tak pernah bisa dijawab oleh pemerintahan Mesir kala itu. ${ }^{6}$

Semasa hidupnya, Sayyid Quth menulis lebih dari dua puluh buku. Ia mulai mengembangkan bakat menulisnya dengan membuat buku untuk anak-anak

\footnotetext{
${ }^{6}$ Anugerah W., Sayyid Quthb; Tokoh Intelektual sejati, dipublikasikan melalui http://www.hudzaifah.org/modules.php?op=modload\&name=News\&file=article\&sid=188 diakses pada tanggal 03 januari 20018.
} 
yang meriwayatkan pengalaman Nabi Muhammad saw. dan cerita-cerita lainnya dari sejarah Islam. Perhatiannya kemudian meluas dengan meulis cerita-cerita pendek, sajak-sajak, kritik sastra, serta artikel untuk majalah.

Di awal karier penulisannya, ia menulis dua buku mengenai keindahan dalam alQur'an: at-Tashwîr al-Fanni fî al-Qur'an dan Musyâhidât al-Qiyâmah fi al-Qur'an (Hari Kebangkitan di dalam al-Qur'an).

Pada tahun 1948, ia menerbitkan karya monumentalnya al-'Adâlah al-Ijtimâ'iyah fí al-Islam (Keadilan Sosial di dalam Islam) kemudian disusul Fî Zhilâl al-Qur'an (Di bawah Naungan al-Qur'an) yang diselesaikan di dalam penjara.

Sewaktu dalam tahanan, ia menulis karya terakhirnya Ma'âlim fî ath-Tharîq (Petunjuk jalan) tahun 1960. dalam buku ini. Ia mengemukakan gagasannya tentang perlunya revolusi total, bukan semata-mata pada sikap/ lingkup individu, namun juga pada struktur negara. Selama periode inilah, logika konsepsi awal negara Islamnya Sayyid Quthb mengemuka. Buku ini pula yang dijadikan bukti utama dalam sidang yang menuduhnya bersekongkol hendak menumbangkan rezim Nasser.

Tetes darah perjuangan dan goresan penanya mengilhami dan meniupkan ruh jihad di hampir semua gerakan keislaman di dunia ini.

\section{Metode Sayyid Quthb dalam Menafsirkan Ayat-ayat tentang Kepemilikan dan Harta dalam Tafsir "Fî Zhilâl al-Qur'ân"}

Secara umum, metode penafsiran yang digunakan oleh Sayyid Quthb adalah metode tafsîr bi ar-ra'yi, di mana corak pemikiran dan pemahaman Sayyid Quthb terlihat lebih dominan dalam upayanya menafsirkan al-Qur'an. Walaupun demikian, tafsir yang dilakukannya bukanlah termasuk dalam kategori tafsîr bi ar-ra'yi al-madhmum. Sayyid Quthb masih memperhatikan batasan-batasan syari'ah dalam menafsirkan al-Qur'an. Ia tidak lantas mengesampingkan apa yang telah menjadi aturan tetap Allah swt. dan tuntunan Rasulullah saw. sehingga tafsirnya tidak bertentangan dengan kaidah agama.

Hanya saja, sesuai dengan latar belakang kehidupan beliau yang notabene merupakan pengikut aktif/ pimpinan gerakan ikhwanul muslimin, maka tak heran jika pembahasan mengenai jihad lebih banyak ia tekankan dalam buku tafsirnya tersebut. Sayyid Quthb menganggap bahwa Allah swt. menciptakan manusia semata-mata untuk selalu berjuang di jalan-Nya. Apapun yang dilakukan oleh manusia selain jihad adalah sia-sia.

Secara implisit, metodologi Sayyid Quthb dapat kita baca pada beberapa kalimat yang penulis kutip dari mukaddimah tafsir yang ditulisnya, antara lain.

"Manhaj/ sistem Ilahi sebagaimana yang tampak di bawah naungan al-Qur'an (sebagai ilham ditulisnya Fî Zhilâl al-Qur'an) dibuat untuk bekerja pada setiap lingkungan, pada setiap perkembangan manusia, dan pada setiap keadaan sari berbagai keadaan jiwa manusia. 
Ia dibuat untuk manusia yang hidup di muka bumi ini, yang memegang fitrah manusia, kemampuan dan persiapannya, kekuatan dan kelemahannya, serta keadaan-keadaan dengan segala perubahan yang senantiasa menimpanya."7

"Syari'at Allah swt. bagi manusia merupakan salah satu Undang-undang-Nya yang menyeluruh di alam semesta. Maka, pelaksanaan syariat ini pasti memiliki dampak yang positif di dalam menyerasikan perjalanan hidup manusia dengan perjalanan alam semesta.

Syari'at tak lain adalah buah iman. Ia tidak mungkin dapat berjalan sendiri tanpa pondasinya yang besar. Syari'at dibuat untuk dilaksanakan pada masyarakat muslim dan ia juga dibuat untuk memberi saham di dalam membangun masyarakat muslim.

Syari'at saling melengkapi dengan konsep Islam yang menyeluruh terhadap wujud yang besar dan eksistensi manusia serta apa yang ditimbulkan oleh konsepsi ini, yaitu ketakwaan hati, kesucian perasaan, besarnya kemauan, akhlak yang luhur, dan perilaku yang lurus.

Manusia juga termasuk salah satu kekuatan alam dengan kerja dan kemauannya, iman dan kesalehannya, serta ibadah dan aktifitasnya."8

Dari kutipan di atas dapat dipahami bahwa Sayyid Quthb berupaya menjadikan bukunya sebagai pedoman hidup menyeluruh bagi umat manusia berdasarkan tuntunan al-Qur'an. Ia berkeyakinan bahwa alam semesta nerikut umat manusia di dalamnya tidak akan pernah menemukan kebahagiaan dan kedamaian hakiki kecuali dengan kembali kepada Allah swt. (dengan mengikuti anjuran dan petunjuk-Nya).

Adapun sistematika penulisan tafsir yang digunakan dalam buku Fî Dhlâl alQur'an adalah sebagai berikut.

a. Sayyid Quthb memulai tafsirnya dengan menyusun, mengelompokkan, dan mengaitkan ayat-ayat yang berhubungan terlebih dahulu.

b. Menjelaskan maksud dari ayat secara global, biasanya dengan menyebutkan sebab turunnya ayat jika ada.

c. Menafsirkan kandungan ayat dengan menyebutkan ayat lain/ hadits yang senada, membahas arti ayat dari segi bahasa, menegaskan hal-hal yang dianggap penting dan berhubungan dengan perilaku manusia, meluruskan interpretasi keliru yang berkembang di masyarakat, diakhiri dengan mencoba memaparkan bentuk aplikasi ayat dalam kehidupan sosial masyarakat. ${ }^{9}$

Metode Sayyid Quthb dalam memaknai konsep harta dapat diketahui dari penafsiran beliau atas firman Allah swt.,

\footnotetext{
${ }^{7}$ Sayyid Quthb, Fî Zhilâl al-Qur'an, terjemah oleh As'ad Yasin, Abdul Aziz Salim Basyarahil, Muchotob Hamzah, Gema insani Press, cet III april 2006, juz I, hal. 16

8 Ibid, juz I, hal. 20

${ }^{9}$ Afaf Ali Nagar, as-Sirâj al-Munîr fị Manâhij al-Mufassirîn, diktat kuliah Ushuluddin, konsentrasi Tafsir dan Ilmu-ilmu al-Qur'an, Unpublished. Hal. 118
} 


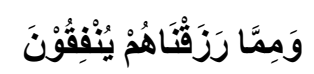

“...dan mereka (yang) menafkahkan dari harta yang kami rizkikan kepada mereka." (al-Baqarah [2]: 3)

Sayyid Quthb menjelaskan bahwa, pada dasarnya orang-orang yang bertakwa mengakui bahwa harta yang ada pada mereka adalah mutlak pemberian (rizki dari) Allah swt. dan mereka tidak memiliki andil dalam mendapatkan harta tersebut. Dengan adanya pengakuan atas nikmat tersebut dapat menumbuhkan ketaatan pada sang Pemberi nikmat dan rasa solidaritas antar sesama makhluk yang sama-sama berhak mendapatkan kebaikan dari-Nya.

Aplikasi dari kedua sikap tersebut adalah pandangan setiap indvidu (yang bertakwa) bahwa hidup tidak akan berjalan dalam satu arus sehingga mereka menjadikankehidupan sebagai lapangan/ sarana tolong menolong, bukan peperangan dan pertengkaran. Selain itu, ia sadar bahwa manusia pada hakekatnya adalah lemah dan tidak memiliki kemampuan apapun. Mereka merasa bahwa hidup mereka hanyalah berpatokan pada hati, rasa, dan jiwa. Bukan kuku, pencakar, dan taring (keserakahan materi). ${ }^{10}$

Demikian pula penafsiran beliau mengenai firman Allah swt.,

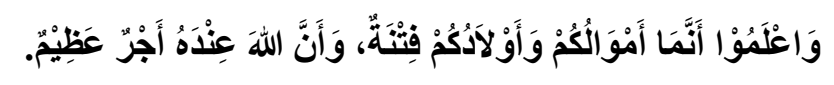

"Dan ketahuilah, bahwa hartamu dan anak-anakmu itu adalah fitnah, dan di sisi Allah-lah pahala yang besar." (al-Anfâl [8]: 28)

Mengenai fitnah harta dan anak dalam surah Al-Anfâl di atas, Sayyid Quthb menyebutkan korelasinya dengan tema amanah dalam surat yang sama,

"Hai orang-orang yang beriman, janganlah kamu mengkhianati Allah dan Rasul (Muhammad) dan (juga) janganlah kamu mengkhianati amanat-amanat yang dipercayakan kepadamu, sedang kamu mengetahui." (Al-Anfâl [8]: 27)

Menurutnya, harta dan anak merupakan objek ujian dan cobaan Allah swt yang dapat menghalangi seseorang dari menunaikan amanah Allah dan Rasul-Nya dengan baik, padahal kehidupan yang mulia adalah kehidupan yang menuntut pengorbanan dan menuntut seseorang agar mampu menunaikan segala amanah

${ }^{10}$ Sayyid Quthb, Fî Zhilâl al-Qur'an, (Beirut: Dar Ihya' at-Turats), jilid I, hal. 41. 
kehidupan yang diembannya. Oleh karena itu, melalui ayat ini Allah swt ingin memberi peringatan kepada semua khalifah-Nya agar fitnah harta dan anak tidak melemahkannya dalam mengemban amanah kehidupan dan perjuangan agar meraih kemuliaan hidup di dunia dan di akhirat. Dan inilah titik lemah manusia di depan harta dan anak-anaknya. Sehingga peringatan Allah akan besarnya fitnah harta dan anak diiringi dengan kabar gembira akan pahala dan keutamaan yang akan diraih melalui sarana harta dan anak. ${ }^{11}$

Pada realitasnya, menurut Sayyid Quthb, tidak ada kebaikan sedikitpun pada tindakan dan perilaku berlomba-lomba dalam usaha mengejar dunia, bahkan sebaliknya justru akan menimbulkan konflik, kerusakan dan huru hara di atas muka bumi ini. Sedangkan sebaliknya, berlomba-lomba untuk meraih apa yang disediakan Allah SWT akan mampu mengangkat dan membersihkan diri manusia. Karena bagaimananapun kenikmatan dunia itu hanya berlangsung sesaat dan sangat cepat sirna. Manakala apa yang ada di sisi Allah akan kekal dan berlangsung tanpa batas.

Firman Allah swt.,

"Apa yang di sisimu akan lenyap, dan apa yang ada di sisi Allah adalah kekal. Dan sesungguhnya Kami akan memberi balasan kepada orang-orang yang sabar dengan pahala yang lebih baik dari apa yang telah mereka kerjakan." (An-Nahl [16]: 96) ${ }^{12}$

Pada tataran aplikasinya, ayat di atas dan ayat yang semakna dengannya merupakan motivasi terbesar bagi para sahabat dalam menjalankan ketaatan kepada Allah swt. sehingga mereka senantiasa berlomba dan ingin lebih dahulu melakukan kebaikan dibanding saudaranya yang lain. Sebut saja misalnya Abu Bakar dan Umar bin Khattab ra. Ketika pada suatu hari Rasulullah saw. meminta para sahabatnya untuk menginfakkan apa yang dimilikinya dari harta, makanan dan senjata yang bisa dimanfaatkan dalam perang. Maka spontan Umar bin Khattab berkata kepada dirinya, "Demi Allah, saya akan mendahului Abu Bakar dalam kebaikan ini."

Umar yakin bahwa dirinya mampu menginfakkan lebih baik dari Abu Bakar. Kemudian ia membagikan hartanya menjadi dua bagian; satu bagian untuk keluarganya dan satu bagian lagi diserahkan untuk Rasulullah saw. Rasulullah tersenyum bangga melihat perilaku sahabatnya dan memujinya.

\footnotetext{
${ }^{11}$ Attabiq Luthfi, Meraih Pahala dari Fitnah Harta dan Anak, dipublikasikan melalui http://www.dakwatuna.com/ index.php/alquranul-karim/tafsir-ayat/2007/meraih-pahaladari-fitnah-harta-dan-anak/, di dalam http://anugerah.hendra.or.id/pasca-nikah/3-anakanak/meraih-pahala-dari-fitnah-harta-dan-anak/, diakses pada tanggal 03 januari 20018. 12 Attabiq Luthfi, Berlomba-Lomba untuk Akhirat, dipublikasika melalui http://www.dakwatuna.com/index.php/alquranul-karim/tafsir-ayat/2007/berlomba-lombauntuk-akhirat/, diakses pada tanggal 03 januari 20018.
} 
Namun tidak berapa lama kemudian, datanglah Abu Bakar dengan membawa seluruh hartanya. Rasulullah tersenyum bangga seraya bertanya kepadanya, "Lantas apa yang engkau sisakan untuk keluargamu?" Dengan yakin dan penuh tawakkal, Abu Bakar menjawab, "Saya tinggalkan untuk mereka Allah dan RasulNya." Demikianlah sikap orang-orang Abrar dari para sahabat terkemuka Rasulullah saw. Allah memuji mereka dalam firman-Nya,

"Dan orang-orang yang beriman paling dahulu, Mereka itulah yang didekatkan kepada Allah. Berada dalam jannah kenikmatan. Segolongan besar dari orangorang yang terdahulu, dan segolongan kecil dari orang-orang yang kemudian."

\section{(Al-Waqi'ah [56]: 10-14)}

Demikianlah berlomba-lomba untuk meraih surga Allah adalah dengan bersegera melakukan kebaikan dan ketaatan, karena setiap muslim memang dituntut untuk berpacu membuka pintu-pintu kebaikan dan ketaatan kepada Allah SWT.

Dalam tafsirnya fî Zhilâl al-Qur'an, ketika menafsirkan firman Allah swt.,

"Wahai orang-orang yang beriman! Infakkanlah sebagian dari hasil usahamu yang baik-baik dan sebagian dari apa yang Kami keluarkan dari bumi untukmu...." (al-Baqarah [2]: 267)

Sayyid Quthb menyatakan bahwa nash ini mencakup segala hasil usaha manusia yang baik dan mencakup seluruh yang dikeluarkan Allah dari dalam dan dari atas bumi, seperti hasil pertanian maupun hasil pertambangan seperti minyak. Karena itu nash ini mencakup semua harta, baik yang ada pada zaman Rosulullah maupun pada zaman sesudahnya, semua wajib dikeluarkan zakatnya dengan ketentuan dan kadar sebagaimana yang telah dijelaskan oleh Rosulullah dalam sabda beliau, ataupun yang dianalogikan kepada sumber zakat yang telah ada. ${ }^{13}$

Ia memaparkan, "Dan janganlah sebagian kamu memakan harta sebagian yang lain di antara kamu dengan jalan yang bathil dan (janganlah) kamu membawa (urusan) harta itu kepada hakim, supaya kamu dapat memakan sebagian dari harta benda orang lain itu dengan (jalan berbuat) dosa, padahal kamu mengetahui.

Urusan peradilan dalam hal harta ini ini pun dihubungkan dengan takwa kepada Allah swt., sebagaimana dalam masalah qishash, wasiat, dan puasa. Semuanya merupakan segmen-segmen yang tersusun rapi dalam tubuh manhaj ilahi yang saling melengkapi. Semuanya diikat dengan tali yang sangat kuat, yang mengikat

\footnotetext{
${ }^{13}$ Iskandar Zulkarnaen, Pengenalan Zakat, dipublikasikan melalui http://www.rumahzakat.org/pengenalan zakat.php?data=7, diakses pada tanggal 03 januari 20018.
} 
segmen manhaj ini secara keseluruhan. Oleh karena itu, manhaj ilahi merupakan satu kesatuan tidak terpilah-pilah dan terpisah-pisah. Maka meninggalkannya satu aspek dan menggunakan aspek yang lain berarti beriman kepada sebagian kitab dan kufur keapda sebagian yang lain, dan pada ujungnya yang demikian itu adalah kufur. Na'udzubillâhi min dâzlik."14

Berkaitan erat dengan harta adalah penguasaan atas harta yang lebih populer dengan kosa kata milik. Menurut Sayyid Quthb, pemilik utama sekaligus mutlak segala sesuatu yang ada dalam kehidupan ini adalah Allah swt. tak ada satu makhluk pun di dunia ini yang memiliki hak menguasai tanpa mengindahkan pemilik yang hakiki, yaitu Allah swt.

Ciri yang sangat menonjol pada tafsir Fî Zhilâl al-Qur'an adalah kuatnya gambaran artistik yang, menurut pendapat Sayyid Quthb, menjadi ciri khas utama uslhûb (ungkapan) Alquran.

Beruntunglah, semasa hidupnya, Sayyid Quthb sempat menulis buku berjudul "At-Tashwîr al-Fanni li Al-Qur'an". Oleh Penerbit Robbani, buku tersebut diindonesiakan dan diterbitkan dengan judul "Keindahan Al-Qur'an yang Menakjubkan: Buku Bantu Memahami Tafsir Fi Zhilalil Quran."

Inilah buku komplementer dalam memahami tafsir Fî Zhilâl al-Qur'an. Tak heran jika dalam menulis tafsirnya, seringkali Sayyid Quthb meminta kepada para pembacanya untuk merujuk buku ini guna memahami sejumlah permasalahan terkait. ${ }^{15}$

\section{KESIMPULAN}

Sebagaimana dijelaskan sebelumnya bahwa, Sayyid Quthb sangat konsen terhadap jihad sehingga dalam setiap karya pemikiran yang ditulisnya tak pernah terlepas dari unsur jihad. Bahkan, metodenya dalam menafsirkan alQur'an di dalam karyanya fí Zhilâl al-Qur'an kerap menjadi referensi di kalangan intelektual muslim Indonesia dalam memahami esensi jihad, di samping buku tafsir al-Manâr karya Rasyid Ridha.

Pada dasarnya, karya pemikiran merupakan ekspresi proses komunikasi penulisnya dengan lingkungan. Dan pandangan itu tidak terlepas dari kecenderungan pribadi, situasi, sosial, politik dan budaya yang melingkupinya. Demikian pula dengan Rasyid Ridha dan Sayyid Quthb, di mana masing-masing dari keduanya memiliki latar belakang modernisme dan fundamentalisme.

\footnotetext{
14 Yulianti Ismail, Tafsir Surat al-Baqarah ayat 188: Jangan Mengambil Harta Orang Lain Secara Bathil, dipublikasikan melalui http://imsa-

sisters.imsa.us/index.php?option=com content\&task=view\&id=299\&Itemid=101, diakses pada tanggal 03 jauari 20017.

15 Irwan Kelana, Keindahan Al-Qur'an, dipublikasikan melalui http://www.republika.co.id/suplemen/cetak detail.asp? mid=5\&id=260339\&kat id=105\&kat i

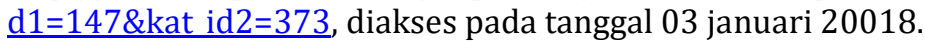


Modernis menganggap jihad sebagai perang yang terjadi pada periode Madinah, dilakukan semata-mata untuk mempertahankan agama (defensif). Sedangkan menurut fundamental, perang untuk menetapkan syariat Allah swt. dalam kehidupan (ofensif). Pada periode ini diartikan Sayyid Quthb sebagai pemisahan secara tegas hubungan antara umat Islam dan non-Islam sehingga ia berkeyakinan bahwa sebagai gerakan, Islam memerlukan kekuatan dan kekuasaan. ${ }^{16}$

Adalah Muhammad Quthb, saudara kandung Sayyid Quthb yang juga merupakan ulama terkemuka, mencoba meluruskan beberapa kesalahfahaman para pembaca yang tidak menghayati karangan Sayyid Quthb dalam tafsirnya fî Zhilâl al-Qur'an secara menyeluruh atau membacanya secara sepintas lalu (pindah dari satu halaman ke halaman lain secara acak) lalu membuat kesimpulankesimpulan yang terburu-buru, yang dapat mencemari persepsi beliau yang sebenarnya tanpa usaha menyelaraskan dan menyatukannya dengan keterangan-keterangan beliau yang lain untuk mendapatkan satu persepsi yang betul-betul ia kehendaki. Selain itu, Muhammad Quthb juga berusaha membantah fitnah yang sengaja diada-adakan oleh musuh-musuh Islam yang begitu bersemangat untuk membunuh karakternya dengan jalan menjelekjelekkan pemikiran islamiyahnya yang tegas dan murni.

Muhammad Quthb sangat memaparkan bahwa pembacaan dan penelitian yang sedemikian cermat dapat menghindarkan pembaca dari kemungkinan terperangkap dalam derasnya arus pemikiran Sayyid Quthb yang begitu meluas dan mendalam. ${ }^{17}$

Dari pemaparan di atas dapat disimpulkan bahwa terkadang pemikiran Sayyid Quthb tidak dapat dipahami dengan mudah kecuali bagi mereka yang mau membacanya dengan teliti disamping memiliki kemampuan bahasa yang baik.

Dan pada akhirnya, pembahasan mengenai metodologi penafsiran Sayyid Quthb dalam memahami ayat tentang harta dan kepemilikan dapat disimpulkan sebagai berikut.

1. Metode yang digunakan oleh Sayyid Quthb adalah metode tafsîr bi ar-ra'yi yang tergolong dalam kategori baik, karena tidak bertentangan dengan apa yang telah ditetapkan Allah swt. berikut tuntunan Rasulullah saw.

2. Sayyid Quthb memaknai harta sebagai segala sesuatu yang dapat dimanfaatkan oleh manusia dalam rangka melaksanakan tugasnya sebagai makhluk Allahdalam membantu makhluk-Nya yang lain dan meninggikan kalimat-Nya (agama Islam) di muka bumi. Selain itu harta adalah sesuatu yang

\footnotetext{
${ }^{16}$ Abdurrahman Mawazi, Menakar Kontekstualisasi Ijtihad, dipublikasikan melalui http://www.media-indonesia.com/resensi/details.asp?id=295, diakses pada tanggal 03 januari 20018.

${ }^{17}$ Administrator website, Tafsir fî Zhilâl al-Qur'an: Ayat-ayat Pilihan, dipublikasikan melalui http://perpustakaanmuslim.freehostia.com/ebook-islam-indonesia/al-quran/tafsir-fi-zilalilquran-ayat-ayat-pilihan/, diakses pada tanggal 03 januari 20018.
} 
dapat dibagi-bagikan sehingga masing-masing makhluk memiliki hak untuk mendapatkannya.

3. Sayyid Quthb berpegang teguh pada keyakinan bahwa harta adalah milik Allah swt. sepenuhnya, apapun bentuknya. Allah swt. adalah sebenar-benar pemilik. Manusia hanya mendapatkan amanah titipan harta untuk dimanfaatkan dalam kehidupannya yang akan mengantarkannya pada akherat.

4. Sayyid Quthb berpandangan bahwa jihad adalah perang ofensif melawan musuh Islam secara fisik dengan cara pemisahan secara total hubungan muslim dan nonmuslim.

5. Berdasarkan pemahaman jihad di atas, Sayyid Quthb beranggapan bahwa harta hanyalah sarana yang harus dimanfaatkan dalam rangka jihad di jalan Allah. Harta bukan untuk dinikmati sendiri oleh individu yang menguasainya.

Demikian sekilas tentang metode yang digunakan oleh Sayyid Quthb dalam memahami ayat-ayat mengenai harta dan kepemilikan dalam tafsirnya fí Zhilâl al-Qur'an berikut kutipan beberapa ayat berkenaan dengan hal tersebut. 


\section{DAFTAR PUSTAKA}

Anugerah W., Sayyid Quthb; Tokoh Intelektual sejati, dipublikasikan melalui http://www.hudzaifah.org/modules.php?op=modload\&name=News\&file $=$ article $\&$ sid $=188$

Arbi', Muhlis Yusuf, "Metodologi Penafsiran Al-Qur'an", published on http://akangjabrik.wordpress.com/2007/12/14/metodologi-penafsiranal-qur\%E2\%80\%99an/

Dahlan, Abdul Aziz ed., 1996, Ensiklopedi Hukum Islam, Jakarta: Ikhtiar Van Hoeve

Ismail, Yulianti, Tafsir Surat al-Baqarah ayat 188: Jangan Mengambil Harta Orang Lain Secara Bathil, published on http://imsasisters.imsa.us/index.php?option=com content\&task=view\&id=299\&Item $\underline{\mathrm{id}=101}$

Kelana, Irwan, Keindahan Al-Qur'an, published on http://www.republika.co.id/suplemen/cetak detail.asp?mid=5\&id=2603 $\underline{39 \& k a t \text { id }=105 \& \text { kat id } 1=147 \& \text { kat id } 2=373}$

Luthfi, Attabiq, Berlomba-Lomba untuk Akhirat, dipublikasika melalui http://www.dakwatuna.com/index.php/alquranul-karim/tafsirayat/2007/berlomba-lomba-untuk-akhirat/

Mawazi, Abdurrahman, Menakar Kontekstualisasi Ijtihad, published on http://www.media-indonesia.com/resensi/details.asp?id=295

Nagar, Afaf Ali, as-Sirâj al-Munîr fî Manâhij al-Mufassirîn, diktat kuliah Ushuluddin, konsentrasi Tafsir dan Ilmu-ilmu al-Qur'an, Unpublished.

Quthb, Sayyid, Fî Zhilâl al-Qur'an, Beirut: Dar Ihya' at-Turats

Quthb, Sayyid, Fî Zhilâl al-Qur'an, terjemah oleh As'ad Yasin, Abdul Aziz Salim Basyarahil, dan Muchotob Hamzah, 2006, Gema insani Press

Salma, Abu, "Sejarah Tafsir dan Perkembangannya", dipublikasikan melalui http://www.geocities.com/abu amman/Tafsir.htm/accesse

Website, Administrator, Tafsir fî Zhilâl al-Qur'an: Ayat-ayat Pilihan, published on http://perpustakaanmuslim.freehostia.com/ebook-islam-indonesia/alquran/tafsir-fi-zilalil-quran-ayat-ayat-pilihan/

Zulkarnaen, Iskandar, Pengenalan Zakat, published on http://www.rumahzakat.org/pengenalan zakat.php?data $=7$ 